\title{
Environmental Ethics: Anthropocentric Chauvinism as Seen in Western Ethical Theories
}

\author{
Rajesh.K, Rajasekaran.V
}

\begin{abstract}
The first ethical dogmas are imparted by parents and elders; however societies strongly believe only the documented proofs. So their ideas are attributed as document forms for historical evidences in philosophical view. These shreds of evidence have their origin from Ancient Greek Western ethical theories, and they consist of clever advices on how to live happily, to avoid unnecessary troubles, and to gain progress in one's career. It is also helpful for rulers to judge people and treat them impartially. Unfortunately, these western ethical theories have eventually developed as more anthropocentric, and humans have started cultivating a chauvinistic attitude towards both nonhumans and natural resources or environment. Anthropocentrism plays a crucial role in the field of environmental ethics and environmental philosophy. This paper mainly deals with environmental ethics, which is the human ethical liaison between people and the natural world and the sort of opinion people create about the environment based on this relationship. Further it analyses how western ethical theories (misinterpretation of biblical teaching and applied normative ethics utilitarianism, Kantian ethics, and Aristotle's virtue ethics) have given importance to human intrinsic values and how this anthropocentric chauvinism of the western ethical theories is the root of our present environmental crisis. It also proves that we are facing global crisis today not because how the ecosystems function but rather because of the immoral functioning of our ethical system.
\end{abstract}

Keywords:- Western Ethical Theories, Environmental Ethics, Environmental Philosophy, Anthropocentricism, Chauvinism, Intrinsic Values.

\section{INTRODUCTION}

Anthropocentrism derived from Ancient Greek. In Greek anthropos means "human being" and kentron means "center". Anthropocentrism claims in philosophical perspective that human beings are the essential or chief creature in the world. This is a basic belief fixed in many Western religions and philosophies. Anthropocentrism represents that humans are different and higher to nature and clasp that human life has inherent value while other creatures are resources that may precisely be exploited for the assistance of humankind (Encyclopedia Britannica). ${ }^{1}$ The term Anthropocentrism is used in different forms humanocentrism, homocentrism and human exceptionalism or human supremacism by some environmentalists. Anthropocentrism plays a crucial role in the field of

Revised Manuscript Received on April 12, 2019.

Rajesh.K, Research Scholar, VIT University, Chennai Campus, Chennai- 600 127, Tamilnadu, India. (Email: rajeshphd18@gmail.com), Ph: 7598679718, Orcid id: orcid.org/0000-0003-4547-8182

Dr. Rajasekaran.V, Assistant Professor, VIT University, Chennai Campus, Chennai-600127, Tamilnadu, India. (Email: rskaran2003@gmail.com), Ph: 09894614338, Orcid id: orcid.org/00000002-1760-4973 environmental ethics and environmental philosophy. (Anthropocentrism, Encyclopedia Britannica). ${ }^{1}$

Chauvinism is an exaggerated version of patriotism. Patriotism and nationalism may represent agreeable pride. Whereas chauvinism is intemperate (Chauvinism, Encyclopedia Britannica). ${ }^{2}$ It can be defined as an irrational belief in the superiority or dominance of one's own group or people. Richard and Val Routley (now Richard sylvan and Val Plumwood) use the term human chauvinism for the strong view that morality is "ultimately concerned entirely with humans, than non-humans" (Against the Inevitability of Human Chauvinism). ${ }^{3}$ Lynn White Jr. has stated that the Anthropocentric arrogance of Christianity toward the nature is the root cause for environmental Crisis (The Historical Roots of Our Ecological Crisis). ${ }^{4}$

Environmental ethics is the ethical relationship between people and the natural world. (Internet Encyclopedia of Philosophy). ${ }^{5}$ In the present days, we can easily understand that our planet is at the verge of peril because of over usage of technology. Recourses like water, sand, trees and land are used lavishly for our flexibility and killing animals for the sake of fulfilling our convenience and comfort instead of needs is also not uncommon. So, the environmental ethics tries to remind us about our relationship with nature and it reflects on how we directly or indirectly cause environmental crisis not only with an effect on the present but also with great impact on the future.

\section{BIBLICAL APPLICATION TO ENVIRONMENTAL ETHICS}

\subsection{Classical Restraint against the Nature}

In the early Britain History, after Romans have occupied the Britain, spreading of Christianity has happened in between 400 and 409 AD. Meanwhile, in the Great Britain, most of the Celts people have got converted into Christianity (A companion to Ancient History). ${ }^{6}$ After they have converted as Christians, they have started to believe that the foundation of the Christian application to environment is based on the holy Bible. But in related to ethical concern, biblical teaching is not obvious, and humans have got confused with the biblical teachings, especially related to ethical issues. They have started chauvinism over the natural world. So it is seen by many as anthropocentric attitude. Aristotle's teachings of hierarchical order assert that "plants exist for the sake of animals, animals for the 
sake of humans, and that inferior men are natural slaves of the superior" (Politics, Book 1) ${ }^{7}$ and Jame Shaefer in his chaper Valuing the Goodness of the Earth has mentioned that these people "John Chrysostom, Augustine, and Thomas Aquinas, when reflecting on the creation story, valued all types of creatures, living and non-living, intrinsically for their unique goodness and instrumentally for the sustenance they provide to others, they valued most highly their complex interrelation in the physical world."'(Caring for Creation). ${ }^{8}$ Australian moral philosopher Peter Singer has criticised this type of chauvinism over the natural world in his book Practical Ethics that "According to the Dominant Western tradition, the natural world exists for the benefit of human beings. God does not care how we treat it. Human beings are the only morally important members of this world. Nature itself is of no intrinsic value. ... Harsh as this tradition is, it does not rule out concern for the preservation of nature, as long as that concern can be related to human well-being" (Practical Ethics, The Environment). ${ }^{9}$ Plato in his Critias blames the humans that humans are the reason for the deforestation of Attica, and it leads to soil erosion and loss of springs; he says that "what now remains compared with what then existed is like the skeleton of a sick man, all the fat and soft soil having wasted away, and only the bare framework of the land being left" (Encyclopedia of Environmental Ethics and Philosophy). ${ }^{10}$

\subsection{Anthropocentricism and the Creation of Nature by God}

Most of the ethicists have comprehend that the roots of anthropocentrism is the book of Genesis and the JudeoChristian Bible (Anthropocentrism, Encyclopedia Britannica). ${ }^{1}$ In the story of formation of nature, God first created five great elements: Ether, Air, Fire, Water and Earth (Ayurveda Amritwani, Pancha mahabhutas) ${ }^{11}$ and "God called the dry land Earth, and the waters that were gathered together he called Seas. And God saw that it was good" (Genesis 1:10). ${ }^{12}$ After the formation of land and seas, God has blessed them and said that "Be fruitful and multiply and fill the waters in the seas, and let birds multiply on the earth" (Genesis 1:22). ${ }^{12}$ Still God has been unsatisfied with what he has formed "And God created man in his own image, in the image of God created he him; male and female created he them" (Genesis 1:27). ${ }^{12}$ After he created male and female in the exact way as he is, "And God said, Let us make man in our image, after our likeness: and let them have dominion over the fish of the sea, and over the birds of the heavens, and over the cattle, and over all the earth, and over every creeping thing that creepeth upon the earth" (Genisis 1:26). ${ }^{12}$ Here, according to Peter Singer, this command of God is the root cause of our environmental problems, and God has given Eden garden to human to preserve and protect "And Jehovah God took the man, and put him into the garden of Eden to dress it and to keep it" (Genesis 2:15). ${ }^{12}$ Here, we can understand that all creatures animals, birds and trees are the same formation by God and all creatures have the same value, and the natural world is inherently good. But the human attitude towards the environment is typical, and he thinks that only human beings are formed in the image of God, and only humans have intrinsic value. So he has started dominating over other creatures and has started destroying them for the sake of his own likeness, whereas it is an action that could destroy the nature. This sinful attitude is considered as anthropocentric chauvinism. So, Lynn White, Jr (a professor of the medieval historian at Princeton) has condemned the attitude of Christianity in his article The Historical Roots of Our Ecological Crisis . It is clear that these Biblical teachings still prevail in our attitude toward nature; he says, "No new set of basic values has been accepted in our society to displace those of Christianity. Hence, we shall continue to have a worsening ecologic crisis until we reject the Christian axiom that nature has no reason for existence than serving man" (The Historical Roots of Our Ecological Crisis). ${ }^{4}$ This formation of nature by God has been illustrated as a clue of human chauvinism to nature and as the exposal of the attitude of human to focus on the instrumental value of nature. At the end, human beings have deliberated that the natural world has worth only if it is profitable to human race. So, these ideas are not only a part of Jewish and Christian theology but also there in Aristotle's Politics and as well as in normative ethics (Anthropocentrism, Encyclopedia Britannica). ${ }^{1}$

\section{APPLYING NORMATIVE ETHICS TO ENVIRONMENTAL ETHICS \& RESULTS}

Normative ethics is the inquiry of moral duty or action. It is the stem of philosophical ethics that evaluate the set of questions that arise when considering how one is ought to act and speak morally (Meta-ethics, Normative Ethics, and Applied Ethics). ${ }^{13}$ It consists of Utilitarian approach, Kantian ethics and Virtue ethics.

\subsection{Utilitarianism}

Utilitarianism is one of the prominent approaches to normative ethics in the history of philosophy. Utilitarianism has its origin mainly in ancient period in Greece, but it is evolved by many philosophers. Among them Epicurus is a main figure and he gives a clear opinion about utilitarianism that the pleasure is very essential for one's life and only because of pleasure we can judge the things correctly and effectively in our life. So, pleasure plays an important role in taking a good decision, and it also maintains good standard (Letter to Menoeceus). ${ }^{14}$ According to Epicurean's theory of hedonism, "gaining of pleasure and the avoidance of pain is the single standard by which we determine happiness and thereby judge our actions" but later some moral philosophers have started to give more importance to the role of virtue and will of God than pleasure. (Utilitarianism From Moral Philosophy through the Ages). ${ }^{15}$ So, Epicurean idea of utilitarianism has not gained any considerable acknowledgement until the nineteenth century and after that English philosophers and economists like Jeremy Bentham and John Stuart Mill have again found out the idea of Epicurean hedonism and have started working on it. According to them, "an action is right if it tends to promote happiness and it is wrong if it tends to produce the reverse of happiness. It is not only just the happiness of the performer of the action but also that of 
everyone who is affected by it" (An Introduction to the Principles of Morals and Legislations). ${ }^{16}$ For example, there are six patients in a hospital and only five bottles of medicine is available to rescue them. In this circumstance, one patient needs all five medicines and another five patients need only one medicine each one instead of five medicines. So the doctor saves five lives instead of giving all five medicines to on patient. In this, utilitarian theory has taken 'the greatest amount of good for the greatest number' and they do not think about consequences (Utilitarianism). ${ }^{17}$

At last Bentham and Mill have the conclusion that the sentient entities pain and pleasure are intrinsic value and they add animals in utilitarian calculus in the basic manner, whereas in practical, only human sentient entities have taken to their calculations (An Introduction to the Principles of Morals and Legislation). ${ }^{16}$ Likewise, Peter Singer argues that animal pain is not calculated in utilitarianism calculations because animals cannot feel sentient entities outwardly like human (The Animal Liberation Movement, Peter Singer $)^{18}$. Here, we can easily understand that utilitarian theory focuses only on paramount of satisfaction by the moral action in a particular time and do not think about the future. So only because of human sentient entities of pain and pleasure, utilitarian theory gives least concern to nonhuman and abandons the environment. Neglecting the duty of preservation of environment and taking sudden decision for temporary pleasure lead to problems in the permanent future.

\subsection{Kantian Ethics}

Immanuel Kant, a German philosopher, is a central figure in modern philosophy. Kant strictly says that we are not supposed to do some actions like killing, stealing and being deceitful even when they give happiness or in cases where the action would bring about more happiness than another (Kantian Ethics). ${ }^{19}$ He argues that the human mind creates the structure of human experience, which is the source of morality. Kant has taken "good will" as the centre of ethics and a basic eligible quality to perform a moral duty. $\mathrm{He}$ attempts to bring the moral dominion from theories or empirical observations back to individuals, in their exercise of freedom. Based on the theories of Kant, the actions may be a right or wrong but should fulfill their own duty and do not think or bother about the consequences (Kantian Ethics). ${ }^{19}$ Morality cannot be based on the evidence of the senses; it is the inherent sense of morality. The objective of an act to be called 'moral', is not the benefit or pleasure or satisfaction; an act is 'moral' only if it is done from a sense of duty and nothing else and it comes from the mind (not empirical evidence).

Kant has alleged that there is an ultimate rule of morality, and he refers ethics (morality) as The Categorical Imperative ( $\mathrm{CI}$ and imperative is a command). The $\mathrm{CI}$ actuates what our good (moral) duties are and to determine the right from the wrong. There are three formulations in the categorical imperative. The first formulation is "act only on that maxim which you can at the same time will to be a universal law" (Kantian Ethics). ${ }^{19}$ It means do your duty with good will and that should be accepted by universal law. For example, a nurse has done a treatment to a patient, who may be a terrorist. Here the nurse's job is a good will, and she has done her duty to rescue the patient's life. It is accepted by universal law. The second formulation is "act so that you treat humanity, whether in your own person or in that of another, never as a means only but at always at the same time as an end" (Kantian Ethics). ${ }^{19}$ It means only a human can behave rationally. Here a nurse has done the treatment for a terrorist patient. It is rational because she has treated the terrorist as a human. So, when the nurse has done her job that should be the end. The third formulation is autonomy formula that is "the idea of the will of every rational being as a will that legislates universal law" (Kantian Ethics). ${ }^{19}$ It means the nurse's treatment of a terrorist as a part of duty may cause harm and pain in the short run: so there has to be an immortal soul as the agent to achieve the good sought in the life time. According to Kant, moral obligation and morality are implied within us and is always a matter of conscious choice (Kantian Ethics). ${ }^{19}$ Duty is to be performed only for its own sake and nothing else- duty for duty sake.

There are some problems in the application of Kantian theory. The first formulation is "act only on that maxim which you can at the same time will to be a universal law" (Kantian Ethics). ${ }^{19}$ Based on this formulation those who have good will can do their moral duty and especially the good will is only accepted by the universal law. If a normal person or a lay man wants to do something good for society, without good will, he is not eligible to do a moral duty and the universal law may not be ready to accept it. Though, in the name of good will, he or she can do a rational thing which is affected to natural world or environment and it is damningly accepted by universal law. So this type of universal law and their terrible actions surely affect not only the society but also natural world especially nonhumans. In second formulation, "act so that you treat humanity, whether in your own person or in that of another, never as a means only but at always at the same time as an end" (Kantian Ethics). ${ }^{19}$ In this particular formation, we can easily observe that even though he or she has done harm to non humans or natural world, they should always be treated as humans even if they are enemies or robbers. So, Kant has given more importance to the humans even if they have chauvinistic attitude towards animals, plants and environment and their actions are irrational. So with these formulas, we can strongly understand that Kantian theories are totally an extension only for the sake of wellness of human beings and his rules are totally against the environmental ethics, especially nonhumans.

\subsection{Virtue Ethics}

According to Aristotle, a virtue (arête) is a character of a particular person. It is very helpful when it comes to achieve a good life. He argues that life should be lead in according with a particular reason or a situation. There are mainly two types of virtues in Virtue ethics, first one is intellectual virtue and second one is moral virtue. Intellectual virtues are natural and are developed from teaching; whereas, moral virtues come from the experiences, 
as an outcome of day to day actions, but not from nature. In Nicomachean Ethics, Book 2, Aristotle concentrates on moral virtues, traits of character (Aristotle on virtue).$^{20}$ For him, it is just means of doing the right thing, at the right time, in the right way, in the right amount, towards the right people. It is based on the idea of virtue, and virtue theory does not spend time telling persons to what to do in a particular situation like the other ethical theories like categorical imperative or principle of utility. Virtue theory emphasizes an individual character rather than following a set of rules and regulations. If an individual can just focus on being good, the right action will pursue naturally. Because there is no need to be specific if an individual is virtuous and they know what to do in all the time according to that particular situation. They know how to tackle themselves and how to go well along with others. He or she can judge their circumstances according to what is right in a particular situation. So, Aristotle has understood that virtue is a burst character trait and a virtuous person understands the situation and behaves accordingly. Virtuous people assess the situation and they know their own attitudes and take action right in the particular situation. So virtue, the burst character is finding the right way to act. Always the right action is the midpoint of two extremes. Example, if there are two extremes of vice in both sides of virtue, virtue action placed in a midpoint and it depends on the situation (Aristotle on virtue).$^{20}$ Aristotle says that virtue is a skill, a way of living and that can only really be learned through experience. (Practical Wisdom: Aristotle Meets Positive Psychology). ${ }^{21}$ He also adds that virtue is a practical wisdom and character is developed through habitation- If he or she does a virtuous thing over and over again, eventually it becomes a part of that person's character. It may be sometimes a copy of ideas from others, but it will change the character.

In virtue ethics, we have observed that actions are spontaneous, the spontaneity to act according to the situation. However, we cannot give a specific relation to matters because each circumstance is unique and it is strongly decided by an individual himself in each situation. The Moral superiority of virtue ethics is basically biting one's nail with pleasures and pains and they do terrible things because of pleasure and may depart from good things because of pain. In this case, virtue ethics strongly work only for sentient entities (humans) and never think about the environment or other entities. So virtue ethics is strongly considered as anthropocentric and these anthropocentric attitudes definitely harm our natural world.

\section{CONCLUSION}

In short, the western ethical theories have misunderstood biblical teachings and applied normative ethics of utilitarianism, Kantian ethics and Aristotle's virtue ethics. All these have taught parallel common themes: they all concentrated more on humans and their sentient entities of pleasure and pain and anthropocentric chauvinism towards others (non-sentient entities and the environment or natural world). Especially, Kantian approach to environmental ethics is considered as pessimistic and faulty interpretation of indirect duties regarding nature. This anthropocentric chauvinism of the western ethical theories are the roots of our present environmental crisis. So we are facing global crisis today not because how the ecosystems function but rather because of the immoral functioning our ethical system.

\section{REFERENCES}

1. Boslaugh, Sarah E. "Anthropocentrism." Encyclopædia Britannica. Encyclopædia Britannica, Inc., 11 Jan. 2016. Web. 14 Sept.

2017.

https://www.britannica.com/topic/anthropocentrism

2. The Editors of Encyclopædia Britannica. "Chauvinism." Encyclopædia Britannica. Encyclopædia Britannica, Inc., 29 Aug. 2007. Web. 14 Sept. 2017 https://www.britannica.com/topic/chauvinism

3. Routley, Richard and Val. "Against the Inevitability of Human Chauvinism". In Ethics and Problems of the 21st Century by K.E Goodpaster, \& K.M. Sayre (eds.), 36-59. Notre Dame, In: University of Norte Dame Press, 1979. Retrieved 14 Sept. 2017 from the World Wide Web: https://iseethics.files.wordpress.com/2013/02/routley-richardand-val-against-the-inevitability-of-human-chauvinism.pdf

4. White, Jr. Lynn. "The Historical Roots of Our Ecologic Crisis." Science 155.3767 (1967): 1203-207. JSTOR. Web. Retrieved 14 Sept. 2017 from the World Wide Web: http://aud.ac.in/upload/Lyn\%20White_Hist\%20roots\%20of\% 20ecological\%20crisis.pdf

5. Internet Encyclopedia of Philosophy. N.p., n.d. Web. 14 Sept. 2017. http://www.iep.utm.edu/envi-eth/

6. Erskine, Andrew. A Companion to Ancient History. Chichester: Wiley-Blackwell, 2013. Web. 16 Sept. 2017. http://www.kavehfarrokh.com/wpcontent/uploads/2010/02/Erskine_ed._2009_A_Companion_t o_Ancient_History_Blackwell_Companions_to_the_Ancient_ World1.pdf

7. Aristotle, The Politics of Aristotle, trans. into English with introduction, marginal analysis, essays, notes and indices by B. Jowett. Oxford, Clarendon Press, 1885. 2 vols. Vol. 1. Retrieved 14 Sept. 2017 from the World Wide Web: http://oll.libertyfund.org/titles/579

8. Caring for Creation, Christian Reflection a series in faith and ethics. N,p. n.d. Web. 19 Sept. 2017. http://www.baylor.edu/content/services/document.php/180850 .pdf

9. Singer, Peter. Practical Ethics. New York: Cambridge University Press, 1993. Retrieved 14 Sept 2017 from the World Wide Web: http://www.stafforini.com/txt/Singer\%20$\% 20$ Practical\%20ethics.pdf

10. Callicott, J. Baird, and Robert Frodeman. Encyclopedia of Environmental Ethics and Philosophy. Farmington Hills, MI: Gale, 2009. Print

11. "Pancha Mahabhutas- Five Great Elements." Ayurveda Amritvani. N.p., n.d. Web. 19 Sept. 2017. http://www.ayurvedaamritvani.com/pancha-mahabhutas--five-great-elements.html

12. The Holy Bible: 1611 edition, King James Version of the Holy Scripture. Retrieved 14 Sept 2017 from the World Wide Web:

http://www.heraldmag.org/olb/bsl/Library/BIBLES/KJV/KJV .pdf

13. Online Guide to Ethics and Moral Philosophy. N.p., n.d. Web. $14 \quad$ Sept. 2017 <http://caae.phil.cmu.edu/Cavalier/80130/part2/II_preface.ht $\mathrm{ml}>$.

14. Cook, Vincent. "Letter to Menoeceus." Epicurus - Letter to Menoeceus. N.p., n.d. Web. 14 Sept. 2017. http://www.epicurus.net/en/ menoeceus.html. 
15. Fieser, James. Utilitarianism from Moral Philosophy Through the Ages. Retrieved 14 Sept 2017 from the World Wide Web: https://www.utm.edu/staff/jfieser/class/300/utilitarian.htm

16. An Introduction to the Principles of Morals and Legislation. Retrieved 14 Sept 2017 from the World Wide Web: https://socserv2.socsci.mcmaster.ca/econ/ugcm/3113/bentham/ morals.pdf

17. Mill, Stuwart . Utilitarianism. Retrieved 14 Sept 2017 from the World Wide Web: http://www.earlymoderntexts.com/assets/pdfs/mill1863.pdf

18. Singer, Peter. The Animal Liberation Movement. Retrieved 14 Sept 2017 from the World Wide Web: https://nwveg.org/files/Singer_The_Animal_Liberation_Move ment.pdf

19. Wood, Allen W. Kantian Ethics. Cambridge: Cambridge UP, 2011. Print. http://uwch 4.humanities.washington.edu/Texts/KANT/CAMBRIDGE EDITION/Secondary/Kantian\%20Ethics\%20(CUP\%202008) $\% 20 \% 20$ Allen\%20W.\%20Wood.pdf

20. Aristotle on virtue document published by Routledge, Taylor and Francis. Retrieved 15 Sept 2017 from the World Wide Web: http://s3-euw1-ap-pe-ws4-cws-documents.riprod.s3.amazonaws.com/9781138793934/A22014/ethical_the ories/Aristotle\%20on\%20virtue.pdf

21. Schwartz, Barry, and Kenneth E. Sharpe. "Practical Wisdom: Aristotle Meets Positive Psychology." Journal of Happiness

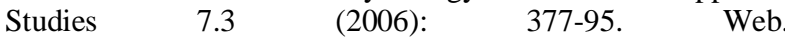
https://www.swarthmore.edu/SocSci/bschwar1/WisdomJHS.p df 